\title{
Testicular Sparing Surgery For A 5-Year- Old Boy with Sertoli's Cell Tumour of the Testis: Case Report
}

\author{
Karim AL-Araji \\ University of Babylon, College of Medicin, Babil.Iraq. \\ Karimalaraji@yahoo.com
}

Submission date:- 11/6/2018 Acceptance date:- 21/6/2018 Publication date:- 3/12/2018

Keywords: Testicular Cancer; Sertoli's cell tumor; child; Gynecomastia; Testicular sparing surgery.

\begin{abstract}
Introduction: Steroli's cell tumors SCT are rare testicular tumor. Very few cases were published in the literature. A new case of Sertoli's cell tumor that is reported and treated by testicular sparing surgery.

Case Presentation: A 5-year-old boy with Sertoli' cell tumor presents with gynaecomastia and precocious puberty. He was treated by successful testicular sparing surgery.
\end{abstract}

Conclusions: SCTs are rare testicular tumors. Testicular sparing surgery can be applied.

\section{1-Introduction}

Sertoli's cell tumors (SCTs) are tumors of Sertoli cells, which are the feeder of the sperm-producing germ cells [1]. They are very rare type of testicular tumors, forming less than $1 \%$ of testicular cancers and few cases had been reported in the literatures [2],[3],[4]. They come the $2^{\text {nd }}$ commonest type of testicular cancers in children after Ledig's cell tumors [5] .They form in the normally descended testicle [6]. The majority of SCTs of the testes are seen in infants less than 6 months[7] and uncommonly in men older than 50 years of age[8]. Nearly almost all patients with testicular neogrowth presents with testicular mass and $10 \%$ of them presents with gynaecomastia and precocious puberty due to increased estrogen secretion[6],[9],[10],[11]. Most of them behave a benign behavior and only $10 \%$ are malignant [2],[6] usually in adults not in children [3],[8],[12]. The gold standard treatment of any testicular neoplasms is orchiectomy [8],[12] but being mostly benign in children, testicular sparing surgery should be thought of for cosmetic and functional purposes [1],[5],[6].

\section{2- Case Presentation}

A 5-year-old boy with bilateral gynaecomastia since when he was two months old was referred for urological evaluation. He was completely healthy before. He had no history of any drug intake and no family history of testicular cancers. O/E, he looks healthy more mature than his age compared to his siblings Fig. 1. 


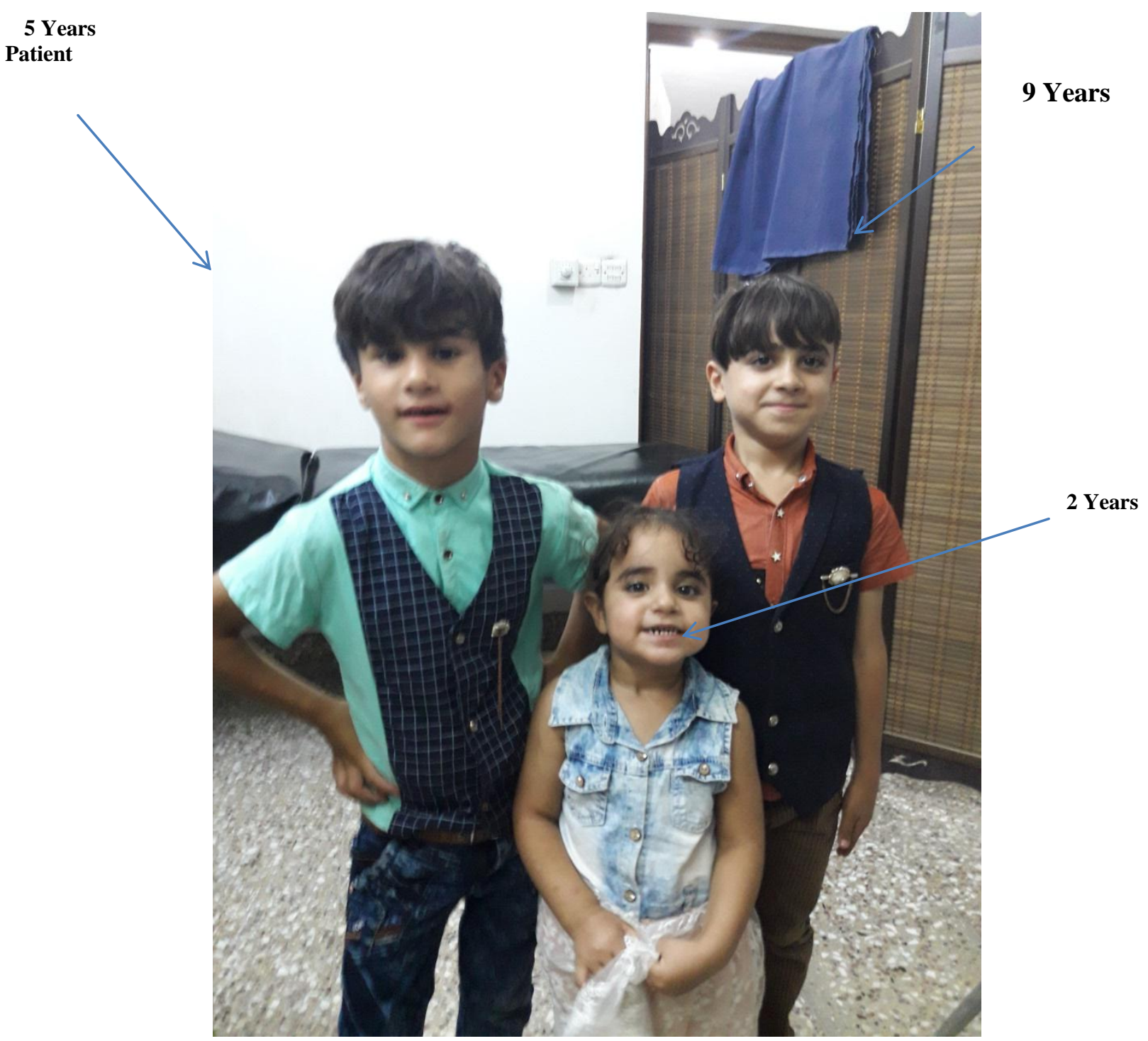

Figure 1: Precocious Puberty

Both breasts were enlarged and on palpation there were bilateral discoid, firm \& mildly tender breast enlargement under the nipple. No axillary lymphadenopathy Fig. 2. 


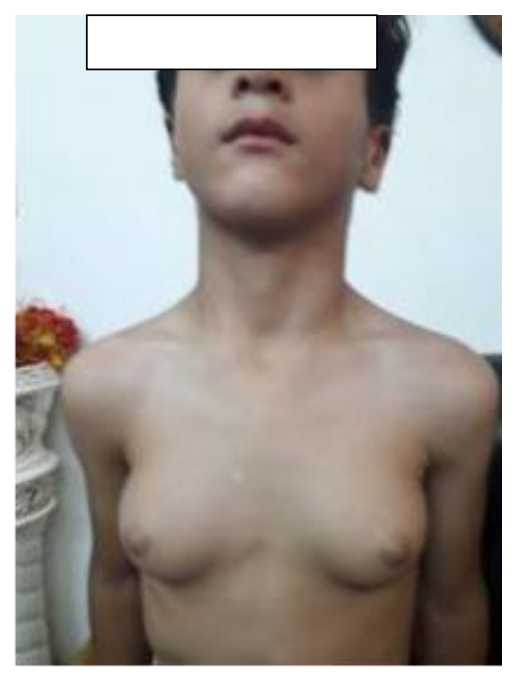

Figure 2: Bilateral Gynecomastia

Examination of the scrotum revealed a $3 \mathrm{~cm}$ firm, well localized and mildly tender mass at the lower pole of the left testis Fig. 3, the right testis was normal.

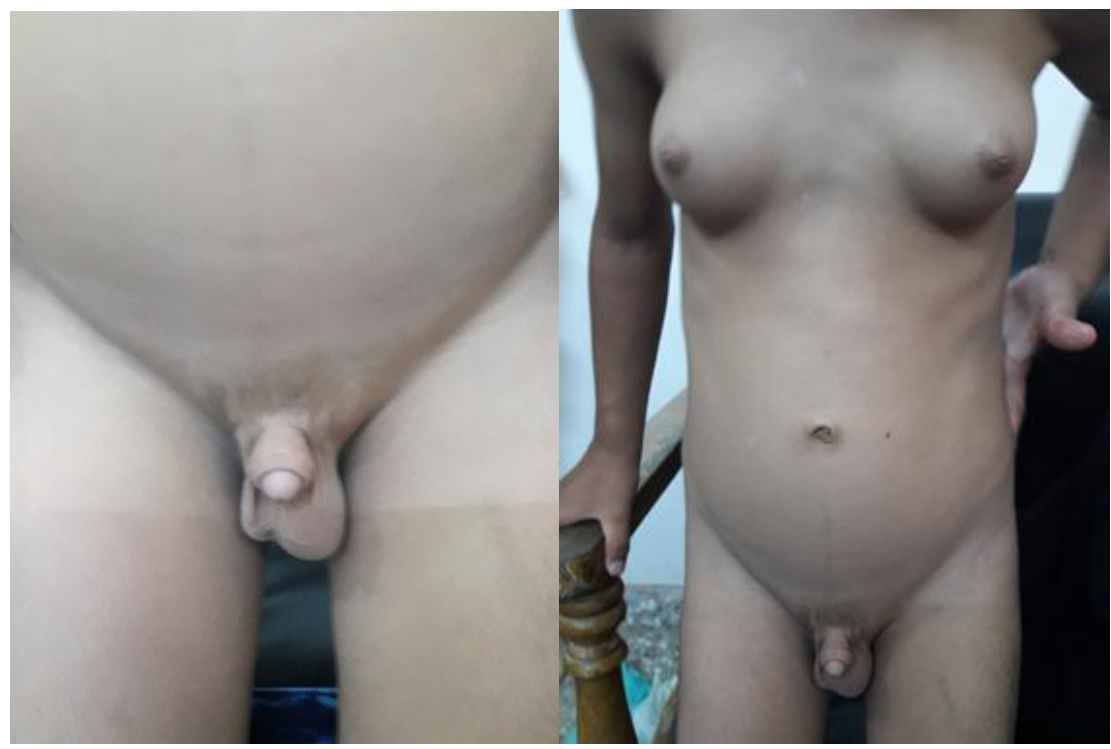

Figure 3: Left testicular mass

Abdominal examination revealed no organomegaly. Chest was clear. Scrotal ultrasound showed a hypoechoeic mass in the lower pole of the left testis of about $34 \times 32 \times 31 \mathrm{~mm}$. Blood investigation, Liver function tests were normal. Alpha-fetoprotein, B- human chorionic gonadotropin ( $\beta$-hCG), Testosterone, Estradiol, Progesterone, LH, FSH, Prolactin, TSH were all normal. Abdominal ultrasonography was normal.

Owing to the presence of the functional testicular mass in a child, the patient was taken to the operating theatre for radical orchiectomy but being mostly benign, testicular sparing surgery may be considered.

\section{3- Surgical procedure}

After a proper informed consent from the patient and his relatives regarding left orchiectomy, the left testis was explored through left inguinal incision, the spermatic cord was controlled early with atraumatic clamp, the testicle was delivered to the wound. On palpation of the left testicle, there was about $3 \mathrm{~cm}$ firm to hard well defined mass at the lower pole of the left testis. It was easily enucleated completely with preservation of normal testicular tissue. Cut sections of the tumor revealed yellowish discoloration of the tumor and the specimen was sent for histopathological examination Fig. 4. 


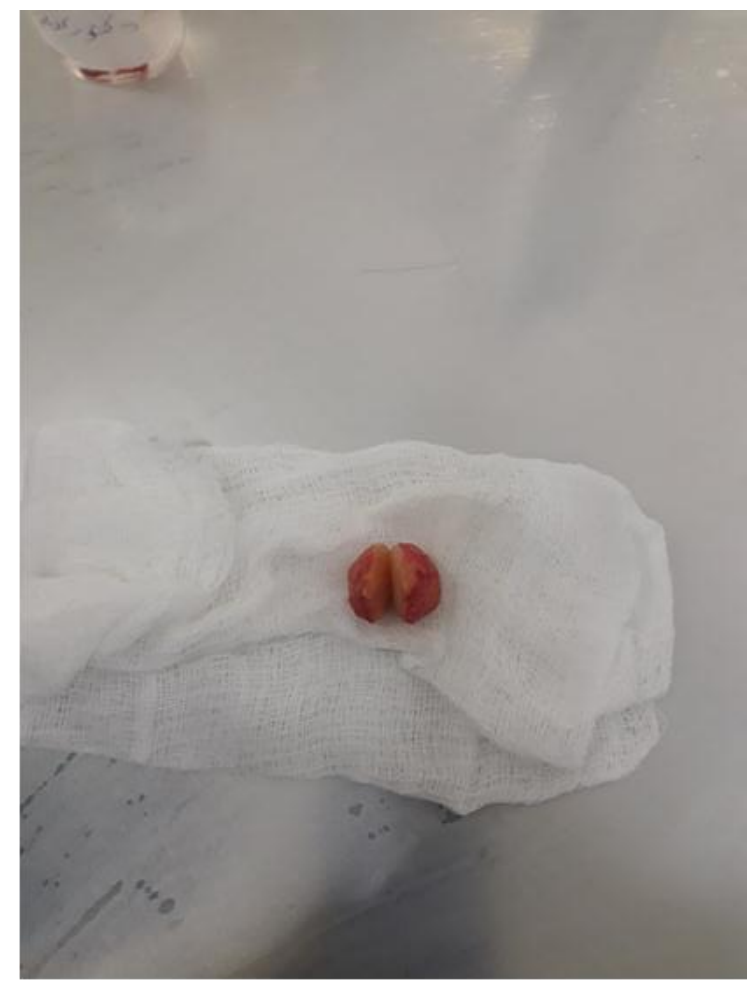

Figure 4 : The tumor after complete excision.

The histopatological examination showed Sertoli cell adenoma ( Myer's type 1) with no evidence of increased mitotic activity. The line of excision was free of tumor. After surgery gynaecomastia regressed gradually and disappeared after 18 weeks. Follow up for 18 months, by physical examination and ultrasonography there was no recurrence of the tumor and no testicular atrophy.

\section{4-Discussion}

This five-year-old boy presents during infancy with gynaecomastia, which is similar to other case reports ${ }^{(8,9,10,12)}$. Development of the tumor in a normally positioned testis is similar to another study ${ }^{(6,9)}$. Liver function tests, Alfafetoprotein \&B- human chorionic gonadotropin ( $\beta$-hCG) were within normal, which is compatible to other studies ${ }^{8,10}$ ). Although he presented with gynaecomastia, the estradiol level was unexpectedly normal. This is unusual and different from what was seen in other studies and gynaecomastia cannot be explained unless on the basis androgen insensitivity ${ }^{(8,9,12)}$. These tumors are usually benign in children ${ }^{1,2}$ and $10 \%$ are malignant and only 21 patients were reported to be malignant ${ }^{11}$. There is no way to confirm their benignity neither by tumor markers nor ultrasonography except by frozen section ${ }^{(8,12)}$ which was not available to our patients. This is considered as a deficiency of this study. The size of the tumor ( $3 \mathrm{~cm}$ in size) is not consistent with what was published as it was usually smaller ${ }^{(9,12)}$. The gold standard treatment of any testicular neoplasm is radical orchiectomy ${ }^{(12)}$ but Sertoli's cell tumor being mostly benign in children, testicular sparing surgery in a form of enucleation at line of cleavage between the tumor and the testis should be thought of for cosmetic and functional benefits ${ }^{(1,5,7,11)}$. This need to be done after being confirmed by frozen section which unfortunately may not available all the time ${ }^{(12)}$. This is critical regarding preoperative informed consent about the possibility of radical orchiectomy. For the above mentioned reason, testicular sparing surgery was applied to this patient The and proved to be effective during 18 months postoperative follow up by physical examination and ultrasonography without testicular atrophy and recurrence of the tumor.

\section{5- Conclusion}

Any patient with gynaecomastia need urological evaluation to find the cause. The fact that Sertoli's cell tumors are usually benign in children encourages selective application of testicular sparing surgery in their treatment. These tumor being very rare and the long term sequel of such treatment is not well known makes long term follow up a wise option. 


\section{CONFLICT OF INTERESTS}

There are no conflicts of interest.

\section{References}

[1] Giovanni Cecchetto, Rita Alaggio, Gianni Bisogno et al; Sex cord-stromal tumors of the testis in children; A clinicopathologic report; Journal of pediatric surgery.

[2] Turk J Urol; Testis-sparing surgery of unilateral testicular large-cell calcifying Sertoli cell tumor: a sporadic case; • DOI: 10.5152/tud.2017.69345. 2017.

[3] US \& Canadian Academy of pathology Section ; Sex Cord-Stromal Tumors of Testis by John Srigley.

[4] Frank N Moore; Liang , Cheng et al; Pathology of Sex Cord Stromal Testis Tumor: Definition, Epidemiology ... Updated: May 10, 2017 , https://emedicine.medscape.com /article/ 1611815- overview May 10, 2017.

[5] Drew C. Baird, MD, and Garrett J. Meyers, MD, Carl R.; Am Fam Physician. Feb 15;97(4):261-268. 2018.

[6] Sreelakshmi1, Anunayi J2, V.V.Sreedhar3, Lavanya Motrapu4, Keerthi Prakash K5, K.; Malignant Sclerosing Sertoli Cell Tumour of Testis: A Rare Case Report with Review of Literature; Sch J Med Case Rep; 2(3):201-203. 2014.

[7] CatherinePatte,FredericHameury,NicolasKalfa et al ; Specificities of sex-cord stromal tumors in children and adolescents; Bulletin du Cancer; Volume 102, Issue 6, June 2015, Pages 550-558; https://doi.org/10.1016/j.bulcan. 04.012. 2015.

[8] Ignacio Gómez García, Marta Romero Molina, Antonio López-García Moreno, Elena Buendía González, Emilio Rubio Hidalgo, Eduardo ;Sertoli Cell Tumor, A Rare Testicular Tumor, Our Experience And Review Of The Literature; Case Reports; Arch. Esp. Urol. 63 (5): 392-395. 2010.

[9] Sarah Coleman, MD, ${ }^{1}$ Yagil Barazani, MD, ${ }^{1}$ Andres A Roma, MD, ${ }^{2}$ and Edmund Sabanegh, Jr, MD’ Rev Urol. 16(4): 191-193. 2014.

[10] Kusuma Venkatesh, Mahantappa Hemalata, S. Sathyavathi, Satish Kumar; Sertoli cell tumor arising in a cryptorchid testis presenting as a content of inguinal hernial sac; Indian Jour $n$ al of Pat hology and Microbiology; 372374. 2016 .

[11] Giovanni Cecchetto, Rita Alaggio Gianni Bisogno et al; Sex cord-stromal tumors of the testis in children. A clinicopathologic report from the Italian TREP project; Journal of Pediatric Surgery; Volume 45, Issue 9, September 2010, Pages 1868-1873; https://doi.org/10.1016/j.jpedsurg. 02.120.2010.

[12] Marte Antonio and De Rosa Laura ;Testis-Sparing Surgery for Benign Pathologies in Children: A Report of Two Cases; Journal of Surgical Techniques and Procedures; 30 March, Volume 2, Issue 1, Article 1013 ; page 1-3. 2018.

\section{عملية المحافظة على الخصية في معالجة ورم سارتولي: حالة مسجلة}

يعتبر ورم سارتولي للخصية من الأورام النادرة و هناك حالات قليلة جدا مسجلة. في هذه المقالة حالة جديدة لورم الخصية نم تسجيلها

لحالة ولد عمره ه سنوات يعاني من تورم الثذيين و النضوج المبكر بسبب ورم سارنتولي في الخصية اليسرى ومعالجته بعملية المحافظة

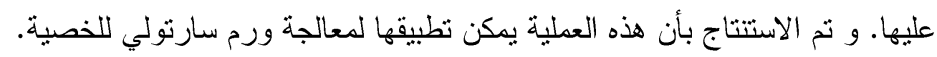

الكلمات الدالة: ورم الخصبة, ورم ساتولي, طفل,تضخم الثذيين, عملية المحافظة على الخصية. 